\title{
ULOGA EMPATIJE U ODNOSU INTELIGENCIJE I KRIMINALNOG RECIDIVIZMA
}

\author{
MARTINA LOTAR RIHTARIĆ ${ }^{1}$, IVANA VRSELJA ${ }^{2}$, ĐULIJANA BADURINA-SERTIĆ ${ }^{3}$ \\ ${ }^{1}$ Edukacijsko rehabilitacijski fakultet, Zagreb, ${ }^{2}$ Hrvatsko katoličko sveučilište, Odjel za psihologiju, Zagreb, ${ }^{3}$ Centar za \\ dijagnostiku u Zagrebu, Uprava za zatvorski sustav, Ministarstvo pravosuđa Zagreb, kontakt: martina.lotar.rihtaric@erf.hr \\ Primljeno: 10.06.2017. \\ Izvorni znanstveni rad \\ Prihvaćeno: 27.10 .2017 \\ UDK: 159.97:343.95
}

Sažetak: Brojni istraživači (npr. Farrington, 2003; Joliffe i Farrington, 2004) navode kako je potrebno bolje proučiti mehanizam povezanosti empatije i činjenja kaznenih djela, pri čemu nude nekoliko objašnjenja istoga. Jedno od njih se temelji na rezultatima sustavnog pregleda istraživanja odnosa empatije i činjenja kaznenih djela, autora Joliffea i Farringtona (2004). Prema ovim autorima, postoji mogućnost da empatija posreduje u odnosu između nekog drugog rizičnog čimbenika i činjenja kaznenih djela, a njihov pregled istraživanja je pokazao da je inteligencija jedan od tih rizičnih čimbenika. Prema tome, kako bismo bolje razumjeli odnos između inteligencije, empatije i kriminalnog recidivizma, cilj ovog rada bio je provjeriti posreduje li empatija u odnosu između inteligencije i kriminalnog recidivizma. Pretpostavilo se da će niža inteligencija predvidjeti izraženiji kriminalni recidivizam samo neizravno, preko smanjene empatije.

Uzorak se sastoji od svih muških zatvorenika (N=1600) koji su u 2013. godini ušli u zatvorski sustav u Republici Hrvatskoj, a sa zatvorskom kaznom duljom od 6 mjeseci. Prosječna dob zatvorenika bila je 39 godina $(S D=11,79)$, a prosječno trajanje zatvorske kazne iznosilo je 27 mjeseci $(S D=34,39)$. Svi zatvorenici su tijekom 2013. u Centru za dijagnostiku u Zagrebu bili na psihodijagnostičkom testiranju. Za potrebe rada, korišteni su podatci o kriminalnom recidivizmu, inteligenciji te empatiji, ali $i$ o crtama ličnosti koje su služile kao kontrola. Kriminalni recidivizam mjeren je ukupnim brojem zatvorskih kazni, inteligencija s Beta testom, empatija sa subskalom empatije iz Eysenckovog upitnika impulzivnosti (IVE), dok su crte ličnosti (psihoticizam, ekstraverzija i neuroticizam) mjerene revidiranim Eysenckovim upitnikom ličnosti.

Rezultati medijacijske analize provedene u PROCESS makrou za SPSS (Hayes, 2012) su pokazali da ne postoji značajan izravan učinak inteligencije na kriminalni recidivizam, ali da postoji značajan neizravni učinak niže inteligencije na izraženiji kriminalni recidivizam preko smanjene empatije. Dobiveni nalazi razmatrani su iz teorijske i praktične perspektive.

Ključne riječi: kriminalni recidivizam, empatija, inteligencija, zatvorenici

\section{UVOD}

\section{Inteligencija, empatija i kriminalno ponašanje}

Brojna su istraživanja pokazala kako je odnos između inteligencije i kriminalnog ponašanja inverzan, odnosno da je niža inteligencija značajan prediktor kriminalnog ponašanja (Ellis i Walsh, 2003). Postoji nekoliko teorijskih objašnjenja navedenog odnosa, a jedno od njih je Kohlbergova (1969, 1975; prema Beißert i Hasselhorn, 2016) teorija moralnog razvoja. Prema ovoj teoriji, nižim stupnjevima moralne prosudbe dominiraju eksternalne posljedice, poput izbjegavanja kažnjavanja te konkretnih pragmatičnih i hedonističkih razmatranja. Viši su stupnjevi, s druge strane, karakterizirani rezoniranjem koje uključuje odnose s drugi- ma u kojima su naglašeni recipročnost, uzajamno poštovanje i povjerenje (Gibbs, 2010; Kohlberg, 1984). Pretpostavlja se da viši stupnjevi moralnog rasuđivanja ublažavaju antisocijalno i delinkventno ponašanje, iz razloga što se na tim stupnjevima razmatra dobrobit odnosa i društva.

Kohlberg i istraživači iz neokohlbegovskog pristupa teorijski elaboriraju i empirijski provjeravaju ideju da su kognitivni i moralni razvoj isprepleteni, te da idu jedan s drugim (Beißert i Hasselhorn, 2016). Moralni razvoj zahtijeva raznolike sposobnosti koje su povezane s kognitivnim procesima $i$ njihovom učinkovitošću: kompleksne situacije trebaju biti interpretirane, važne informacije trebaju biti odabrane i procesirane, informacije trebaju biti integrirane, različite perspektive trebaju biti koor- 
dinirane, posljedice određenih činova se trebaju anticipirati itd. Slijedom navedenog, čini se razumnim pretpostaviti da su za moralno prosuđivanje i odlučivanje potrebne sposobnosti rezoniranja i vještine rješavanja problema (Derryberry i sur., 2005). Budući da se, prema Silvermanu (1994), visoka inteligencija može smatrati sinonimom apstraktnog rezoniranja i kompleksnosti misli, može se pretpostaviti da inteligencija djeluje na moralni razvoj. Drugim riječima, inteligentniji pojedinci donose sofisticiranije moralne prosudbe.

Postojeće spoznaje na ovom području istraživanja sugeriraju da je za moralni razvoj ključan ne samo paralelni razvoj racionalne misli i povezanih socio-kognitivnih vještina, nego i razvoj emocionalnih procesa koji su u temelju empatičnih odgovora na emocionalna iskustva drugih (Eisenberg $\mathrm{i}$ Miller, 1987). Dakle, moralni razvoj nije konceptualiziran samo u terminima moralne prosudbe nego i u terminima njenih emocionalnih faceta, poput empatije. U posljednjih nekoliko desetljeća, kroz psihologijske teorije i istraživanja počela se naglašavati važnost empatije u odnosu na moralni razvoj (Broidy i sur., 2003). Tako Gibbs (2010) navodi da su emocionalne predispozicije poput empatije temeljne za moralni razvoj, motivaciju i ponašanje jednako kao i Kohlbergove strukture kognitivnih stupnjeva. Upravo zbog njene pretpostavljene temeljne uloge u razvoju moralnosti, empatija se opisuje kao „moralna emocija“" (Eisenberg, 2000). Postoje brojne konceptualizacije ove moralne emocije, pri čemu je najprihvaćenija ona koju su predložili Cohen i Strayer (1996). Prema navedenim autorima, empatija je multidimenzionalni konstrukt, koji se sastoji od kognitivne i emocionalne komponente. Kognitivna komponenta empatije odnosi se na sposobnost razumijevanja emocija i osjećaja drugih ljudi, dok se emocionalna komponenta odnosi na sposobnost dijeljenja emocionalnih stanja drugih i doživljavanja njihovih osjećaja (van Langen i sur., 2014; Joliffe i Murray, 2012; Joliffe i Farrington, 2004; Joliffe i Farrington, 2006). Pretpostavlja se da deficiti u empatiji potiču antisocijalno te agresivno ponašanje (Cohen i Strayer, 1996; Broidy i sur., 2003; Joliffe i Farrington, 2007; Jolliffe i Farrington, 2011). Naime, pojedinci koji imaju nižu razinu empatije ne mogu doživjeti ili razumjeti emoci- onalne posljedice antisocijalnih i agresivnih djela po druge ljude, zbog čega je vjerojatnije da će oni biti počinitelji upravo takvih djela. S druge strane, ljudi s visokom razinom empatije mogu razumjeti ili doživjeti strah drugih ljudi, njihova negativna emocionalna stanja te tugu kada netko čini neko antisocijalno djelo. Prema tome, ljudi s niskim razinama empatije nemaju ponašajne inhibicije kao ljudi s izraženom sposobnošću empatičnih doživljaja i razumijevanja. Dvije metaanalize istraživanja odnosa empatije i kriminalnog ponašanja (Joliffe i Farrington, 2004; van Langen i sur., 2014) općenito su pokazale da empatija doprinosi objašnjenju činjenja kaznenih djela. Međutim, obje su metaanalize pokazale $\mathrm{i}$ da je navedeni doprinos $\mathrm{u}$ nekim slučajevima ovisan o inteligenciji počinitelja. Joliffe i Farrington (2004) su taj nalaz dobili sustavnom analizom istraživanja provedenih na uzorcima zatvorenika koji su počinitelji različitih vrsta kaznenih djela, i to za obje vrste empatije. Spomenuti autori navode kako dobiveni nalazi ne upućuju nužno na potrebu odbacivanja koncepta empatije u objašnjenju kriminalnog ponašanja, te predlažu model u kojem je empatija dio kauzalnog lanca između inteligencije i činjenja kaznenih djela. Prema modelu Joliffea i Farringtona (2004), izgleda da je empatija, barem djelomično, odraz intelektualnih sposobnosti, te da onda, zapravo, viša empatija inhibira činjenje kaznenih djela.

\section{Odnos inteligencije i empatije s kriminalnim recidivizmom}

Za razliku od istraživanja koja su se bavila odnosom inteligencije i kriminalnog ponašanja općenito, istraživanja kriminalnog recidivizma nisu dosljedno pokazala da su osobe s nižom inteligencijom sklonije kriminalnom recidivizmu. Specifičnije, metaanaliza koju su proveli Ellis i Walsh (2003) pokazala je da inteligencija zapravo nema veze s kriminalnim recidivizmom. Slično su pokazala i druga istraživanja koja ne potvrđuju direktnu vezu inteligencije i kriminalnog recidivizma (npr. Verhees, 2016; Bonta i sur. 1998; Katsiyannis i Archwamety, 1997).

S druge strane, metaanaliza koju su proveli van Vugt i sur. (2011) pokazala je suprotno kada se radi o odnosu empatije i kriminalnog recidivizma. Spomenuti su autori u svojoj metaanalizi, koja je 
obuhvaćala 19 istraživanja, proučavali odnos između moralnog razvoja i kriminalnog recidivizma, mjerenog putem službenih podataka o počinjenju kaznenih djela i putem samoiskaza delinkvencije nakon prethodnog uhićenja ili osude. Pri proučavanju ovog odnosa, autori su razlikovali moralnu kogniciju od moralnih emocija, koje su uključivale sram, krivnju i empatiju. Rezultati metaanalize su pokazali mali do srednji učinak moralnog razvoja na kriminalni recidivizam, pri čemu je učinak moralnih kognicija na kriminalni recidivizam bio veći od učinka moralnih emocija. Kao jedan od nedostataka ove metaanalize autori navode nemogućnost proučavanja svake moralne emocije zasebno u odnosu na kriminalni recidivizam, uslijed malog broja istraživanja koja su se bavila odnosom navedenih triju moralnih emocija i kriminalnog recidivizma.

Područje istraživanja kriminalnog recidivizma, kao i kriminalnog ponašanja općenito, karakterizirano je nedostatkom istraživanja koja istovremeno proučavaju odnos inteligencije, empatije i povrata činjenju kaznenih djela. Gore navedeni nalazi impliciraju važnost empatije u objašnjenju kriminalnog recidivizma, ali i postojanje mogućnosti da inteligencija ne djeluje izravno na kriminalni recidivizam, nego neizravno preko nekog drugog važnog čimbenika. Možda je upravo empatija taj čimbenik, kako je pretpostavljeno u modelu Joliffea i Farringtona (2004) te jednoj od najznačajnijih psihologijskih teorija, Kohlbergovoj teoriji moralnog razvoja. Stoga će se upravo u ovom radu po prvi puta provjeriti kakav je međuodnos između inteligencije i empatije u objašnjenju kriminalnog recidivizma zatvorenika.

Specifičnije, u radu će se proučiti pokazuje li inteligencija izravan učinak na kriminalni recidivizam, kao i to pokazuje li inteligencija neizravan učinak na kriminalni recidivizam preko empatije. Temeljem modela kojeg su predložili Joliffe i Farrington (2004), očekuje se da inteligencija neće pokazati značajan izravni učinak na kriminalni recidivizam zatvorenika (Hipoteza 1). Isto tako, očekuje se da će inteligencija pokazati značajan indirektni učinak na kriminalni recidivizam preko empatije, na način da će niža inteligencija značajno predvidjeti nižu empatiju, koja će naposljetku predvidjeti izraženiji kriminalni recidivizam (Hipoteza 2).

\section{METODA}

\section{Uzorak}

U istraživanju je sudjelovalo 1689 zatvorenika i zatvorenica (1600 muškaraca) koji su osuđeni na kaznu zatvora višu od 6 mjeseci te su tijekom 2013. godine u Centru za dijagnostiku u Zagrebu bili na administrativnoj i dijagnostičkoj obradi s ciljem kreiranja prijedloga programa izvršavanja kazne zatvora. S obzirom na mogućnost moderatorskog efekta spola u odnosu varijabli iz testiranog modela te prilično malog broja žena u uzorku, za potrebe ovog rada, postavljene hipoteze provjeravane su samo na muškim zatvorenicima.

Dob sudionika ovog istraživanja kreće se od 18 do 80 godina pri čemu prosječna dob iznosi $\mathrm{M}=38,77$ godina $(\mathrm{SD}=11,79)$, a prosječna kazna zatvora iznosi $\mathrm{M}=27,27$ mjeseci $(\mathrm{SD}=34,39)$. Nešto više od petine sudionika (20,9\%) kaznu zatvora dobilo je zbog zlouporabe opojnih droga, 17,4\% zbog krađe ili teške krađe, 9,8\% zbog razbojništva, $7,2 \%$ zbog prijevare, $6,7 \%$ zbog izazivanja prometne nesreće, 5,9\% zbog ubojstva, a 5,5\% zbog nekog od kaznenih djela protiv spolne slobode i spolnog ćudoređa. Ostala kaznena djela imaju znatno nižu zastupljenost.

Recidivizam je u ovom istraživanju operacionaliziran preko broja kazni zatvora na koje je osoba osuđena tijekom svog života uključujući i zatvorsku kaznu koju je osoba služila tijekom provedbe istraživanja. Navedeni podatak preuzet je iz službene dokumentacije zatvorenika. Broj kazni sudionika istraživanja kreće se od 1 do 21 pri čemu prosječan broj kazni iznosi $\mathrm{M}=1,86(\mathrm{SD}=2,07)$. Zatvorenici koji su u životu služili samo jednu kaznu zatvora (onu u vrijeme provedbe istraživanja) predstavljaju nerecidiviste.

\section{Metoda prikupljanja podataka}

Svi osuđenici u Republici Hrvatskoj koji su osuđeni na kaznu zatvora od šest mjeseci na više, smješteni su u Centar za dijagnostiku u Zagrebu gdje stručni tim vrši dijagnostiku na temelju prikupljenih i objedinjenih podataka iz različitih izvora. Stručni tim daje prijedlog programa izvršavanja kazne zatvora za svakog osuđenika u okviru kojeg 
se procjenjuje i rizičnost zatvorenika i vjerojatnost kriminalnog povrata.

Za svakog osuđenika koji je tijekom 2013. godine došao u Centar za dijagnostiku u Zagrebu, prikupljeni su podaci o inteligenciji i empatiji, te o neuroticizmu, psihoticizmu i ekstraverziji kako bi se kontrolirao efekt tih osobina na odnos inteligencije i empatije pri predviđanju kriminalnog recidivizma. Osim toga, prikupljen je i podatak o broju zatvorskih kazni na koje je osoba bila osuđena tijekom života. Broj zatvorskih kazni preuzet je iz službene dokumentacije.

Istraživanje je provedeno uz suglasnost i u suradnji s Upravom za zatvorski sustav Ministarstva pravosuđa. Potrebni podaci prikupljeni su iz baze podataka Centra za dijagnostiku u Zagrebu gdje su i primijenjeni mjerni instrumenti. Iznimno se pazilo na zaštitu i anonimnost podataka i to tako da su iz baze prikupljenih podataka uklonjene sve identifikacijske oznake ili podaci na temelju kojih bi se mogao otkriti identitet zatvorenika.

\section{Mjerni instrumenti}

Inteligencija je mjerena Beta testom (Kellog i Morton, 1943.; prema Kellog i Morton, 1997), dok je za mjerenje empatije primijenjena skala empatije iz Upitnika impulzivnosti (EPQ-IVE) (Eysenck i Eysenck, 1994). Osim toga, primijenjen je i Revidirani Eysenckov upitnik ličnosti (EPQ-R/A) (Eysenck i Eysenck, 1994) za mjerenje osobina ličnosti čiji su učinci u analizama kontrolirani.

Beta test (Kellog i Morton, 1943; prema Kellog $i$ Morton, 1997)

Inteligencija je mjerena Revidiranim beta testom koji se koristi za mjerenje opće inteligencije, pri čemu je posebno pogodan za primjenu kod osoba nižeg stupnja obrazovanja ili niske razine pismenosti. Sastoji se od šest subtestova za ispitivanje prostorne orijentacije, brzine jednostavne transformacije, sposobnosti uviđanja veza i odnosa među situacijama, perceptivnog rezoniranja, sposobnosti uviđanja perceptivnih inadekvatnosti te perceptivne brzine. U ovom radu korišten je kvocijent inteligencije koji se dobiva na temelju ukupnog rezultata na svih šest testova.

\section{Upitnik impulzivnosti (EPQ-IVE) (Eysenck $i$ Eysenck, 1994)}

Upitnik impulzivnosti sastoji se od 54 tvrdnje, a mjeri impulzivnost, avanturizam i empatiju. Skala empatije sastoji se od 19 tvrdnji, a zadatak sudionika je procijeniti je li pojedina tvrdnja za njih točna ili netočna. Iako se u literaturi u kojoj je korištena navedena skala može pronaći informacija kako se pretpostavlja da se skalom ispituje emocionalna empatija (van Langen i sur., 2014), sadržajnom analizom tvrdnji utvrđeno je da se tvrdnje dominantno odnose na emocionalnu empatiju, ali da postoje i tvrdnje koje se odnose na kognitivnu empatiju (npr. Volite li gledati kako ljudi otvaraju darove?).

Unutarnja konzistencija skale impulzivnost za muškarce iznosi $\alpha=0,84$, za skalu avanturizma ona iznosi $\alpha=0,85$, a za skalu empatije $\alpha=0,69$ (Eysenck i sur. 1985, prema Eysenck i Eysenck, 1994).

\section{Revidirani Eysenckov upitnik ličnosti (EPQ-R/A)} (Eysenck i Eysenck, 1994)

Upitnik se sastoji od 106 čestica kojima se mjeri neuroticizam (24 čestice), ekstraverzija (23 čestice) i psihoticizam (32 čestice). Unutarnja konzistencija navedenih skala za muškarce iznosi $\alpha=0,84$ za neuroticizam, $\alpha=0,88$ za ekstraverziju i $\alpha=$ 0,62 za psihoticizam (Eysenck i Eysenck, 1994 ). Također, upitnik sadrži i Skalu laži te Skalu kriminaliteta i Skalu ovisnosti, no rezultati na tim skalama nisu uključeni u ovaj rad zbog mogućnosti pojave multikolinearnosti s obzirom da se ukupan rezultat na njima računa uključivanjem i čestica koje bazično mjere navedene tri osobine ličnosti. Zadatak sudionika je procijeniti je li tvrdnja za njih točna ili netočna. Obzirom da se $\mathrm{u}$ istraživanjima (npr. van Dam, Janssens i Bruyn, 2005) pokazalo da kriminalni recidivizam značajno predviđaju izražene osobine ličnosti ekstraverzije, psihoticizma i neuroticizma, u ovom će se radu kontrolirati učinci ovih triju osobina, a koje, uostalom, nisu glavni predmet interesa $u$ radu.

\section{Strategija obrade podataka}

Prije obrade podataka kojima će se odgovoriti na probleme postavljene $\mathrm{u}$ radu, analizirane su korelacije između varijabli koje su uključene u rad. 
Kako bismo provjerili pokazuje li inteligencija izravan učinak na kriminalni recidivizam, kao i to pokazuje li inteligencija neizravan učinak na kriminalni recidivizam preko empatije, provedena je jedna medijacijska analiza, $\mathrm{s}$ time da su tri mjerene osobine ličnosti (pihoticizam, ekstraverzija i neuroticizam) $\mathrm{u}$ analizi definirane kao kontrolne varijable. Analiza je provedena u PROCESS makrou za SPSS (Hayes, 2012), u kojem se testira značajnost neizravnog učinka pomoću neparametrijskog postupka u kojem se procjenjuju regresijski parametri na osnovi uzastopnog i slučajnog izvlačenja manjih uzoraka sa n-1 sudionika iz originalnog uzorka (Hayes, 2009). Intervali pouzdanosti ovako dobivenih koeficijenata procjenjuju se na temelju dobivenih empirijskih distribucija rezultata uzoraka na temelju kojih možemo točnije testirati značajnost neizravnih učinaka. U literaturi je postignut dogovor istraživača o uzimanju 5000 bootstrap uzorkovanja s 95\% intervalima pouzdanosti (IP) kao najboljoj opciji. Kada rezultati analize pokažu da interval pouzdanosti uključuje nulu, tada govorimo o neznačajnom učinku; kada ne uključuje nulu, tada govorimo o značajnom učinku. Za razliku od metode testiranja medijacije Barona i Kennya (1986), ova metoda ne zahtijeva da prediktor i kriterij budu značajno povezani.

\section{REZULTATI}

Prije provjere značajnosti izravnog i neizravnog učinka inteligencije na kriminalni recidivizam, provjerene su korelacije između inteligencije, empatije i kriminalnog recidivizma te kontroliranih osobina ličnosti (Tablica 1).

Tablica 1. Povezanost inteligencije, empatije i osobina ličnosti s kriminalnim recidivizmom

\begin{tabular}{|l|c|c|c|c|c|}
\hline & 2 & 3 & 4 & 5 & 6 \\
\hline $\begin{array}{l}\text { 1. Kriminalni } \\
\text { recidivizam }\end{array}$ &,$- 10 * *$ &,$- 06 *$ &, $18 * *$ &,- 01 &, $17 * *$ \\
\hline 2. Inteligencija & &, $12 * *$ &,$- 16 * *$ &, $07 *$ &,$- 21 * *$ \\
\hline 3. Empatija & & &,$- 22 * *$ &, $14 * *$ &, $24 * *$ \\
\hline 4. Psihoticizam & & & &, 03 &, $37 * *$ \\
\hline 5. Ekstraverzija & & & & &,$- 06 *$ \\
\hline 6. Neuroticizam & & & & & \\
\hline
\end{tabular}

$* p<, 05 ; * * p<, 01$

Korelacije pokazuju kako je kriminalni recidivizam negativno povezan is inteligencijom is empatijom, pri čemu je važno naglasiti kako je riječ o vrlo niskim korelacijama. Između inteligencije i empatije utvrđena je također niska pozitivna povezanost.

\section{Analiza značajnosti izravnog i neizravnog učinka inteligencije na kriminalni recidivizam}

Rezultati provjere značajnosti izravnog i neizravnog učinka inteligencije na kriminalni recidivizam preko empatije prikazani su u Tablici 2. Kako je vidljivo iz rezultata prikazanih u prvom modelu ove analize, pokazalo se da ne postoji značajan izravan učinak inteligencije na kriminalni recidivizam $(B=-0,00 ; S E B=0,00 ; t=-0,82 ; p$ $=, 41)$, uz kontrolu osobina ličnosti psihoticizma, ekstraverzije i neuroticizma. Ove četiri varijable zajedno objašnjavaju tek 5\% varijance kriminalnog recidivizma. Međutim, rezultati su pokazali da postoji značajan neizravni učinak inteligencije na kriminalni recidivizam preko empatije, pri čemu su u svakom koraku analize postojanja ovog neizravnog učinka kontrolirane osobine ličnosti psihoticizma, ekstraverzije i neuroticizma. Specifičnije, pokazalo se kako viša inteligencija predviđa izraženiju empatiju (Model 2; $\mathrm{B}=0,03$; $\mathrm{SE} B=0,01$; $=5,34 ; \mathrm{p}=, 00)$, a koja onda naposljetku značajno predviđa manje kriminalnog recidivizma (Model $3 ; \mathrm{B}=-0,01 ; \mathrm{SE} \mathrm{B}=0,01 ; \mathrm{t}=-2,90 ; \mathrm{p}=, 00)$. Kako je vidljivo iz Tablice 2, inteligencija, zajedno $\mathrm{s}$ mjerene tri osobine ličnosti, objašnjava čak $20 \%$ varijance empatije, dok sve mjerene varijable (psihoticizam, ekstraverzija, neuroticizam, inteligencija i empatija) objašnjavaju tek $6 \%$ varijance kriminalnog recidivizma.

\section{RASPRAVA}

Brojna dosadašnja istraživanja pokazala su postojanje povezanosti između niže inteligencije i izraženijeg kriminalnog ponašanja, bilo da je riječ o verbalnoj (npr. Moffitt, 1994) ili neverbalnoj inteligenciji (npr. Loney i sur., 1998). S druge strane, kada je riječ o odnosu inteligencije i kriminalnog recidivizma, pregled literature nam pokazuje da su istraživanja koja proučavaju navedeni odnos malobrojna, kao i to da su ona karakterizirana nedosljednošću u svojim nalazima. Tako su neka istraživanja potvrdila prediktivnu vrijednost niže inteligencije 
Tablica 2. Rezultati provjere značajnosti izravnog i neizravnog učinka inteligencije na kriminalni recidivizam preko empatije

\begin{tabular}{|c|c|c|c|c|c|c|}
\hline Prediktori & $\mathbf{B}$ & SE B & $\mathbf{t}$ & $\mathbf{p}$ & 95\% IP donji & 95\% IP gornji \\
\hline Model 1 & \multicolumn{6}{|c|}{ Kriterij: kriminalni recidivizam } \\
\hline psihoticizam & 0,07 & 0,02 & 4,22 &, 00 & 0,0356 & 0,0974 \\
\hline ekstraverzija & 0,00 & 0,01 & $-0,66$ & ,95 & $-0,0241$ & 0,0226 \\
\hline neuroticizam & 0,04 & 0,01 & 4,30 &, 00 & 0,0243 & 0,0651 \\
\hline \multirow[t]{2}{*}{ inteligencija } & $-0,00$ & 0,00 & $-0,66$ &, 51 & $-0,0099$ & 0,0049 \\
\hline & \multicolumn{6}{|c|}{$\mathrm{R} 2=, 05 ; \mathrm{p}<, 01$} \\
\hline
\end{tabular}

\begin{tabular}{|l|c|c|c|c|c|c|}
\hline Model 2 & \multicolumn{5}{|c|}{ Kriterij: empatija } \\
\hline psihoticizam & $-0,32$ & 0,03 & $-12,85$ &, 00 & $-0,3703$ & $-0,2722$ \\
\hline ekstraverzija & 0,13 & 0,02 & 6,94 &, 00 & 0,0941 & 0,1682 \\
\hline neuroticizam & 0,25 & 0,02 & 14,91 &, 00 & 0,2137 & 0,2785 \\
\hline inteligencija & 0,03 & 0,01 & 5,13 &, 00 & 0,0190 & 0,0424 \\
\hline & \multicolumn{7}{|c|}{$\mathrm{R} 2=, 21 ; \mathrm{p}<, 01$} \\
\hline
\end{tabular}

\begin{tabular}{|l|c|c|c|c|c|c|}
\hline Model 3 & \multicolumn{5}{|c|}{ Kriterij: kriminalni recidivizam } \\
\hline psihoticizam & 0,05 & 0,02 & 3,18 &, 00 & 0,0204 & 0,0860 \\
\hline ekstraverzija & 0,00 & 0,01 & 0,38 &, 70 & $-0,0191$ & 0,0284 \\
\hline neuroticizam & 0,05 & 0,01 & 4,87 &, 00 & 0,0328 & 0,0769 \\
\hline inteligencija & $-0,00$ & 0,00 & $-0,32$ &, 75 & $-0,0087$ & 0,0063 \\
\hline empatija & $-0,04$ & 0,02 & $-2,35$ &, 02 & $-0,0758$ & $-0,0068$ \\
\hline & \multicolumn{7}{|c|}{$\mathrm{R} 2=, 05 ; \mathrm{p}<, 01$} \\
\hline
\end{tabular}

Napomena. Ukoliko interval pouzdanosti (IP) ne uključuje nulu, radi se o značajnom učinku. Neizravni učinak inteligencije na kriminalni recidivizam je značajan (učinak=-0,0013; IP donji =-0,0032, IP gornji = -0,0002).

u objašnjenju učestale kriminalne aktivnosti (npr. Fougere i sur.,2015; Beggs i Grace, 2008), dok su druga pokazala kako ne postoji povezanost između inteligencije i kriminalnog recidivizma (npr. Ellis i Walsh, 2003; Bonta i sur., 1998). Iz navedenog je razvidno kako postoji potreba za daljnjim istraživanjima koja bi se bavila razjašnjavanjem odnosa između inteligencije i kriminalnog recidivizma. Obzirom na to da pojave u stvarnom životu ne djeluju u vakuumu, neovisne jedne o drugima, ta bi se istraživanja trebala usmjeriti na proučavanje mogućnosti da je odnos između inteligencije i kriminalnog recidivizma ovisan o nekim drugim varijablama, kao i na proučavanje mehanizama kojima se navedeni odnos može objasniti. Kriminološka je literatura karakterizirana malobrojnošću takvih istraživanja, zbog čega postoje brojne praznine $u$ spoznajama o odnosu između inteligencije i kriminalnog ponašanja općenito, a posebice o odnosu između inteligencije i kriminalnog recidivizma. Stoga je svrha ovog rada bila upravo u pronalaženju novih spoznaja o odnosu između inteligencije i kriminalnog recidivizma, čime bi se ostvario značajan doprinos dostupnoj kriminološkoj literaturi. Tome se pristupilo proučavanjem postoji li izravni odnos između inteligencije zatvorenika i kriminalnog recidivizma zatvorenika, te postoji li navedeni odnos i u slučaju kad se $\mathrm{u}$ ispitivane modele uključi empatija zatvorenika. Navedenim se htjelo proučiti predviđa li inteligencija kriminalni recidivizam preko smanjene empatije, odnosno postoji li medijacijska uloga empatije u odnosu između inteligencije i kriminalnog recidivizma. Polazne hipoteze o odnosima između ispitivanih varijabli postavljene su sukladno postavkama modela Joliffea i Farringtona (2004), a koji dosada nije empirijski provjeravan.

Sukladno postavkama navedenog modela, očekivalo se da inteligencija neće pokazati značajan izravan učinak na kriminalni recidivizam zatvorenika (Hipoteza 1), ali da će pokazati značajan neizravan učinak na kriminalni recidivizam preko empatije, na način da će niža inteligencija značajno 
predvidjeti nižu empatiju, koja će naposljetku predvidjeti izraženiji kriminalni recidivizam (Hipoteza 2). Dobiveni su rezultati pokazali da ne postoji značajan izravan učinak inteligencije na kriminalni recidivizam, čime se potvrđuje prva postavljena hipoteza rada. Ovaj je nalaz u skladu s nalazima nekih istraživanja (npr. Bonta i sur., 1998), kao i s općenitim zaključkom kojeg su iznijeli Ellis i Walsh (2003) u svojoj metaanalizi istraživanja odnosa inteligencije i kriminalnog ponašanja. Prema spomenutim autorima, niža je inteligencija značajan čimbenik u objašnjenju počinjenja prvog kaznenog djela, ali izgleda da ono nema nikakve veze s kriminalnim recidivizmom.

Dobiveni rezultati potvrdili su i drugu hipotezu rada. Iako je doprinos svih mjerenih varijabli u objašnjenju kriminalnog recidivizma prilično nizak (samo 5\% objašnjene varijance), rezultati su pokazali kako odnos između inteligencije, empatije i kriminalnog recidivizma ide u očekivanom smjeru. Inteligencije je pozitivno povezana s empatijom, a empatija je negativno povezana s kriminalnim recidivizmom. Iz navedenog možemo zaključiti kako rezultati ovog istraživanja podupiru model $\mathrm{u}$ kojem empatija ima medijatorsku ulogu u odnosu inteligencije i kriminalnog recidivizma, odnosno kako se odnos inteligencije i kriminalnog recidivizma ostvaruje preko empatije (Joliffe i Farrington, 2004). Odnos inteligencije, empatije i kriminalnog recidivizma $u$ istraživanjima je u potpunosti zanemaren. Obzirom na to, glavni rezultat ovog istraživanja nije moguće usporediti s rezultatima drugih istraživanja. Razmatrajući puteve koji su uključeni u ispitivani neizravni učinak, vidljivo je da niža inteligencija objašnjava relativno velik udio varijance empatije (21\% varijance). Dobiveni nalazi idu u prilog ideji o povezanosti kognitivnog i moralnog razvoja, odnosno empatije kao emocionalne facete moralnog razvoja (Beißert i Hasselhorn, 2016), a koju naglašava teorija moralnog razvoja.

Drugi put koji je uključen u ispitivani neizravni učinak je put od empatije do kriminalnog recidivizma. Kako je vidljivo, učinak empatije na kriminalni recidivizam vrlo je nizak, ali opet statistički značajan, što može biti posljedica velikog uzorka sudionika. Osim toga, dobivene nalaze treba razmatrati s oprezom obzirom na još dva, međusobno povezana metodološka aspekta ovog istraživanja; prvi je vrsta primijenjene mjere empatije, a drugi je populacija na kojoj je ta mjera primijenjena. Mjerenje empatije primjenom skale samoiskaza nikako nije najbolji način operacionalizacije tog konstrukta s populacijom kojom se bavi ovo istraživanje. Zatvorenici čiji su podatci korišteni u ovom istraživanju, po dolasku u Centar za dijagnostiku u Zagrebu, u okviru dijagnostičkog postupka, nalaze se u situaciji u kojoj im je cilj prikazati se u najboljem mogućem svjetlu kako bi si osigurali što povoljnije izvješće stručnog tima s prijedlogom pojedinačnog programa izvršavanja kazne zatvora. U takvom kontekstu motivacija zatvorenika za davanje socijalno poželjnih odgovora je vrlo visoka te je za očekivati da zatvorenici precjenjuju vlastitu empatiju. Robinson i suradnici (2007) navode kako mjere samoiskaza empatije ne uspijevaju ustanoviti važne i očekivane deficite empatije kod osoba koje su u penalnom sustavu. Stoga autori preporučuju korištenje drugih mjera empatije, prvenstveno laboratorijskih. Tako se, primjerice, u jednoj takvoj mjeri empatije pod nazivom Kontinuum empatije (Strayer, 1993), sudionicima putem videa prvo prikazuju određene emocionalno evocirajuće priče, a nakon čega ih se kroz intervju ispituje o njihovim emocionalnim i kognitivnim odgovorima na te priče. Istraživanje koje su proveli Robinson i sur. (2007) je pokazalo da je primjena takvih laboratorijskih mjera pokazala postojanje izraženijih deficita u empatiji kod delinkvenata koji su u sustavu, u odnosu na mlade iz kontrolne skupine, dok mjere samoiskaza empatije nisu pokazale značajne razlike u empatiji između navedena dva uzorka.

Međutim, ne smijemo napustiti ovaj dio rasprave a da ne navedemo i neke prednosti ovog istraživanja. Ovdje prvenstveno treba spomenuti sam način na koji je operacionaliziran kriminalni recidivizam. Naime, podatci o kriminalnom recidivizmu prikupljeni su retrospektivno iz zatvorenikove službene dokumentacije. Kako je riječ o broju zatvorskih kazni izrečenih osobi tijekom njezina cijelog života, izbjegnut je problem prekratkog vremenskog intervala praćenja javljanja recidivizma koji je vrlo čest $u$ istraživanjima koja se bave ovim konstruktom. Osim toga, na ovaj način dobivamo mjeru recidivizma na višoj razini mjerenja koja je ujedno i osjetljivija. Nadalje, 
rezultati ovog istraživanja temelje se na velikom reprezentativnom uzorku zatvorenika u Republici Hrvatskoj. Inozemna istraživanja koja su provođena na populaciji zatvorenika najčešće uključuju manje uzorke koji nisu reprezentativni, već su uglavnom prikupljeni u nekoliko kaznionica ili u samo jednom dijelu zemlje. S obzirom na specifičnosti zatvoreničke populacije, $\mathrm{i} u$ istraživanjima $\mathrm{S}$ većim uzorcima vrlo često dolazi do problema velikog broja zatvorenika koji odbijaju sudjelovanje u istraživanju. Kako u tom slučaju ne možemo znati je li odbijanje sudjelovanja na neki način sustavno, ne možemo govoriti o reprezentativnom uzorku. U ovom istraživanju je i taj problem izbjegnut. Centralizirani sustav u Republici Hrvatskoj u kojem svi zatvorenici s kaznom duljom od 6 mjeseci prolaze ujednačenu obradu u istoj ustanovi, sa stručnjacima različitih profila, omogućava provođenje ovakvog istraživanja na reprezentativnom uzorku koji dozvoljava generalizaciju rezultata na populaciju zatvorenika u cijeloj Republici Hrvatskoj.

Kako je u ovom radu prikazano prvo istraživanje s ciljem provjere postavki modela Joliffea i Farringtona (2004), nakon provedenog istraživanja nameću se i prijedlozi za buduća istraživanja. Autori smatraju važnim provjeriti testirani model i na specifičnim oblicima kriminalnog povrata kao što je na primjer kriminalni povrat za nasilna kaznena djela ili kod počinitelja seksualnih delikata. Rezultati takvih istraživanja pomogli bi u daljnjem rasvjetljavanju uloge inteligencije i empatije u kriminalnom povratu. Osim navedenog, testirani model trebalo bi provjeriti i za drugačije operacio- nalizacije kriminalnog povrata, odnosno uključiti i počinitelje kaznenih djela kojima su izrečene $i$ druge kazneno-pravne sankcije te primjenom neke od mjera samoiskaza za mjerenje kriminalnog ponašanja.

\section{ZAKLJUČAK}

Razmatrajući cjelokupne rezultate ovog rada, općenito se može zaključiti kako su oni u potpunosti potvrdili početne pretpostavke, temeljene na modelu Joliffea i Farringtona (2004). Pokazalo se da ne postoji značajan izravan učinak inteligencije na kriminalni recidivizam, nego da inteligencija pokazuje svoj neizravni učinak na kriminalni recidivizam, preko empatije. Međutim, dobiveni je učinak malen, slijedom čega nije opravdano davati preporuke za tretman zatvorenika. Prije promišljanja o prikladnom načinu primjene ovih rezultata u tretmanu zatvorenika, ipak je nužno provjeriti stabilnost dobivenih učinaka i uz drugačiju operacionalizaciju mjere empatije. Usprkos tome, ostaje činjenica da ovaj rad predstavlja značajan doprinos spoznajama u literaturi, budući da se u njemu po prvi puta, koliko je poznato autorima ovog rada, empirijski provjerava model Joliffea i Farringtona (2004). U dosadašnjim je istraživanjima zanemarivana složenost odnosa ispitivanih konstrukata, te su njihovi zaključci davali prejednostavnu sliku učinaka i inteligencije i empatije na kriminalni recidivizam. Ovaj rad predstavlja značajan odmak od takvih zaključaka, nudeći smjernice za buduća slična istraživanja. 


\section{LITERATURA}

Baron, R.M. i Kenny, D.A. (1986): The moderator-mediator variable distinction in social psychology research: Conceptual, strategic and statistical considerations. Journal of Personality and Social Psychology, 51, 6, 1173-1182.

Beggs, S. M. i Grace, R. C. (2008): Psychopathy, intelligence, and recidivism in child molesters: Evidence of an interaction effect. Criminal Justice and Behavior, 35, 6, 683-695.

Beißert, H. M. i Hasselhorn, M. (2016): Individual differences in moral development: Does intelligence really affect children's moral reasoning and moral emotions? Frontiers in Psychology, 7, 1961.

Bonta, J., Law, M. i Hanson, K. (1998): The prediction of criminal and violent recidivism among mentally disordered offenders: A meta-analysis. Psychological Bulletin, 123, 2, 123-142.

Broidy, L., Cauffman, E., Espelage, D. L., Mazerolle, P. i Piquero, A. (2003): Sex differences in empathy and its relation to juvenile offending. Violence and Victims, 18, 5, 503-516.

Cohen, D. i Strayer, J. (1996): Empathy in conduct-disordered and comparison youth. Developmental Psychology, $32,988-998$.

Derryberry W. P., Wilson T., Snyder H., Norman T., Barger B. (2005): Moral judgment developmental differences between gifted youth and college students. Prufrock J., 17, 6-19.

Eisenberg, N. (2000): Emotion, regulation, and moral development. Annual Review of Psychology, 51, 665-697.

Eisenberg, N. i Miller, P. A. (1987): The relation of empathy to prosocial and related behaviors. Psychological Bulletin, $101,91-119$.

Ellis, L. i Walsh, A. (2003): Crime, delinquency and intelligence: A review of the worldwide literature. U: Nyborg, H. (ur.): The Scientific Study of General Intelligence: Tribute to Arthur R. Jensen (str. 343-365). Oxford: Elsevier Science Ltd.

Eysenck, H. J. i Eysenck, S.B.G. (1994): Priručnik za Eysenckove skale ličnosti. Jastrebarsko: Naklada Slap.

Fougere, A., Daffern, M. i Thomas, S. (2015): Does resilience predict recidivism in young offenders? Psychiatry, Psychology and Law, 22, 2, 198-212.

Gibbs, J.C. (2010): Moral development \& reality. Beyond the theories of Kohlberg and Hoffman (2nd ed.). Boston, MA: Pearson Allyn \& Bacon.

Hayes, A.F. (2009): Beyond Baron and Kenny: Statistical mediation analysis in the new millennium. Communication Monographs, 76, 4, 408-420.

Hayes, A.F. (2012): PROCESS: A versatile computational tool for observed variable moderation, mediation, and conditional process modeling. Preuzeto 10.04.2017. na mrežnoj stranici: http://www.afhayes.com/public/ process2012.pdf.

Jolliffe, D. i Farrington, D. P. (2004): Empathy and offending: A systematic review and meta-analysis. Aggression and Violent Behavior, 9, 441-476.

Jolliffe, D. i Farrington, D. P. (2006): Examining the relationship between low empathy and bullying. Aggressive Behavior, 32, 540-550.

Jolliffe, D. i Farrington, D. P. (2007): Examining the relationship between low empathy and self-reported offending. Legal and Criminological Psychology, 12, 265-286.

Jolliffe, D. i Farrington, D. P. (2011): Is low empathy related to bullying after controlling for individual and social background variables? Journal of Adolescence, 34, 59-71.

Jolliffe, D. i Murray, J. (2012): Lack of empathy and offending: Implications for tomorrow's research and practice. U: Loeber, R. i Welsh, B. C. (ur.): The future of criminology (str. 62-69). Oxford: Oxford University Press.

Katsiyannis, A. i Archwamety, T. (1997): Factors related to recidivism among delinquent youth in a state correctional facility. Journal of Child and Family Studies, 6, 1, 43-55. 
Kellogg, C. E. i Morton, N. W. (1997): Priručnik za revidirani beta test (Beta-II). Jastrebarsko: Naklada Slap.

Kohlberg, L. (1984): Essays on moral development. Volume II. The psychology of moral development: The nature and validity of moral stages. San Fransisco: Harper \& Row Publishers.

Langevin, R. i Curnoe, S. (2008): Are the mentally retarded and learning disordered overrepresented among seks offenders and paraphilics? International Journal of Offender Therapy and Comparative Criminology, 52, 4, 401-415.

Loney, B. R., Frick, P.J., Ellis, M. i McCoy, M. G. (1998): Intelligence, callous-unemotional traits, and antisocial behavior. Journal of Psychology and Behavioral Assessment, 20, 3, 231-247.

Moffitt, T. E. (1994): Natural histories of delinquency. U: E. G. M. Weitekamp i K. J. Kerner (ur.): Cross-national longitudinal research on human development and criminal behavior (str. 3-61). Netherlands: Kluwer Academic Publishers.

Robinson, R., Roberts, W. L., Strayer, J. i Koopman, R. (2007): Empathy and emotional responsiveness in delinquent and non-delinquent adolescents. Social Development, 16, 3, 555-579.

van Dam, C., Janssens, J.M.A.M. i De Bruyn, E.E.J. (2005): PEN, Big Five, juvenile delinquency and criminal recidivism. Personality and Individual Differences, 39, 7-19.

van Langen, M.A.M., Wissink, I.B., van Vugt, E.S., Van der Stouwe, T. i Stams, G.J.J.M. (2014): The relation between empathy and offending: A meta-analysis. Aggression and Violent Behavior, 19, 2, 179-18.

Van Vugt, E., Gibbs, J, Stams, G. J., Bijleveld, C., Hendriks, J. i Van der Laan, P. (2011): Moral development and recidivism: A meta-analysis. International Journal of Offender Therapy and Comparative Criminology, 55, $1234-1250$.

Verhees, E. (2016): Testing the moderator role of intelligence and gender in the relationship between age at first conviction and recidivism among treated offenders. Preuzeto 10.04.2017. na mrežnoj stranici: http://arno.uvt.nl/ show.cgi?fid=142451.

\section{THE ROLE OF EMPATHY IN THE RELATIONSHIP BETWEEN INTELLIGENCE AND CRIMINAL RECIDIVISM}

Abstract: Many researchers (e.g. Farrington, 2003; Joliffe and Farrington, 2004) state that the mechanism linking empathy and offending needs to be better explored, suggesting several ways in which this relationship can be viewed. One of them is based on the results of Joliffe and Farringtons' (2004) systematic review of studies relating empathy to offending. According to these authors, there is a possibility that empathy actually mediates the relationship between some other risk factors and offending. Their review showed that intelligence is one of these risk factors. Therefore, in order to provide a better understanding of the relationship among intelligence, empathy and criminal recidivism, the aim of this study was to examine whether empathy mediates the relationship between intelligence and criminal recidivism. It was hypothesized that lower intelligence would affect intensity of criminal recidivism only indirectly, through lower empathy.

The sample consisted of 1600 male prisoners in the Croatian prison system who had to serve a prison sentence longer than 6 months. Average prisoner age was 39 years $(S D=11.79)$ and duration of the prison sentence was 27 months $(S D=34.39)$. All prisoners came to the Center for Diagnostics in Zagreb during 2013, and they all went through psychodiagnostic testing. For the purposes of this paper, data on intelligence, empathy, personality, and criminal recidivism were used. Criminal recidivism was operationalised as the number of prison sentences during a person's lifetime. Intelligence was measured using the Beta test, empathy using the empathy subscale from the Eysenck Impulsivity Questionnaire, and personality traits (psychoticism, extraversion, and neuroticism) using the Eysenck Personality Questionnaire - Revised/Adult.

Results of mediation analysis conducted using the PROCESS macro for SPSS (Hayes, 2012) showed a nonsignificant direct effect of intelligence on criminal recidivism, and a significant indirect effect of lower intelligence on criminal recidivism via lower empathy. Research findings are discussed from theoretical and practical perspectives.

Key words: criminal recidivism, empathy, intelligence, prisoners 